\title{
The European Union, the World Trade Organization and Cultural Diversity
}

Mira Burri

\section{Introduction}

The increased exchange of goods, services, peoples and ideas across borders, intrinsic to globalisation, have had many and multi-faceted effects. Those affecting culture are amongst the most controversial. The 'trade and culture' quandary could indeed be phrased more revealingly as 'trade versus culture'. It is an area of contestation that emerged in the forum of the World Trade Organization (WTO) and its institutional predecessor, the General Agreement on Tariffs and Trade (GATT). The debate became particularly heated during the Uruguay Round of trade negotiations (1986-1994). The European Community (EC) and its member states played a key role in this battle, which almost turned into a stumbling block of the entire negotiations and ultimately had a strong impact on the design of the WTO Agreements, especially the rules on services.

This chapter maps these developments and the positions of the European Union (EU or the Union) and its member states, which were not always coherent. It also looks at the actual results of the trade versus culture contestation - that is, the rules on trade in goods and services in the WTO and how they reflect the need for more policy space in matters of cultural policy, which the EU so ardently pressed for. The chapter further analyses the evolution of both the international trade regulation and the discourse on cultural policy. This discourse has in fact undergone a major transformation in the last two decades, as it has moved from the 'exception culturelle' rhetoric, which dominated the Uruguay trade talks, towards a more positive but also more pro-active agenda under the slogan of cultural diversity. The EU has been a major driver of this transformation, which has succeeded in mobilising the international community and ultimately led to the adoption of the 2005 UNESCO Convention on the Protection and Promotion of the Diversity of Cultural Expressions. The chapter concludes by appraisal of the current state of the debate situating it into the broader picture of contemporary global governance. It asks how the EU could effectively pursue its cultural policy aspirations and endorse its cultural diversity agenda in a world of complexity and rapid technological change, in particular in view of the affordances of digital media.

\section{A look at the origins of the cultural diversity discourse}

Although the idea of state protection of cultural identity is not exceptional and has existed for many years, possibly going as far back as the origins of sovereignty (Petito, 2001), the international policy debate on the relationship between trade and culture began only after World War I. This has to do with the changing nature of the medium, as well as with the particular period in history. In the former sense, although the printed media, such as books, newspapers and magazines, were the first manifestation of the industrialisation of cultural production, they had relatively low tradability, mostly due to their cultural specificity and the use of local language, 
which made them less appealing to a critical mass of consumers outside the domestic market (Footer and Graber, 2000: 116-117). Audiovisual media, especially film, in contrast, proved more suitable for engaging and appealing to a broader audience. After World War I, the initial predominance of European cinema had subsided and Hollywood had clearly become the new centre of global film-making, exporting visual entertainment in vast amounts (Trumpbour, 2007; Bruner, 2008; Singh, 2008).

As a reaction to this shift of power and fearing both the economic and cultural impact of Hollywood, many European governments introduced measures to protect their domestic film industries, mostly in the form of import and screen quotas. These measures found expression in the 'Special Provisions Relating to Cinematograph Films', which became part of the GATT 1947. Article IV thereof permitted quotas for 'the exhibition of cinematograph films of national origin during a specified minimum proportion of the total screen time', while preserving the general ban on quantitative restrictions on imports (GATT Article XI). The screen quotas under Article IV GATT are a proof that cultural exceptions were indeed accepted by the GATT members. But they also reveal the relatively narrow focus of such exceptions on audiovisual media.

The idea that some measures protecting national cultural industries may be justified was also reflected in bilateral and regional fora. In 1988, the cultural proponents celebrated a major victory when Canadian negotiators introduced a 'cultural exclusion' clause in the Canada-US Free Trade Agreement (CUSFTA). ${ }^{1}$ Five years later, such exclusion was also included in the North American Free Trade Agreement (NAFTA), which incorporated by reference CUSFTA in Annex 2106. ${ }^{2}$ It should be noted, however, that this cultural clause was coupled with a retaliation provision that significantly limited by design its practical use.

The cultural exception proponents were eager to transplant these localised 'successes' into the multilateral context. The tension between trade and culture had intensified at this point of time as technology, especially satellites, increasingly facilitated diffusion of cultural content, not only in film but also in television. Another important reason for the particular intensity of the cultural exception battle fought during the Uruguay Round had to do with the round's special mandate and the significance of its outcomes. The Uruguay Round was not simply aimed at dismantling tariff barriers but was a much further reaching undertaking that ultimately led to the establishment of the WTO with a new structure and an impressively effective dispute settlement mechanism (Jackson, 1997). The WTO, which became operational on 1 January 1995, included domains previously unaffected by international trade regulation - most notably, intellectual property (by means of the Agreement on Trade-related Aspects of Intellectual Property Rights, TRIPS) and services (by means of the General Agreement on Trade in Services, GATS). ${ }^{3}$

\footnotetext{
${ }^{1}$ Canada-US Free Trade Agreement, 22 December 1987-2 January 1988, 27 ILM 281 (1988).

2 North American Free Trade Agreement, 17 December 1992, 32 ILM 289 (1993).

${ }^{3}$ The law of the WTO is contained in several agreements, attached as annexes to the Marrakesh Agreement establishing the WTO. The GATT, GATS and TRIPS are contained in Annex 1 of the WTO Agreement. Other Annexes concern additional aspects of liberalisation such as the dispute settlement procedure (Annex 2), the trade policy review mechanism (Annex 3) and certain plurilateral agreements (Annex 4).
} 
The cultural proponents at the WTO, led by the European Communities ${ }^{4}$ and Canada, had an ambitious goal during the Uruguay Round of negotiations. They aimed at exempting any product or service that is culture-related from the rules of the negotiated WTO Agreements - and hence at establishing an 'exception culturelle'. While they were eager to create such rules that would allow carve-outs for all cultural sectors, it should be again stressed that the main focus of the efforts was upon the exclusion of audiovisual services, as the sensitivities in the media sector were the highest and as other cultural services were less tradable.

Reflecting this narrow focus of the tension, during the Uruguay trade talks, a Working Group on Audiovisual Services was established. Its essential task was to consider whether the special cultural considerations related to the audiovisual sector ${ }^{5}$ demanded its total exclusion from the scope of the services agreement, or whether a dedicated annex to the Agreement would provide a solution. The opinions differed profoundly, and even the diplomatic vernacular of trade representatives could not conceal the chasm between those in favour of free trade and those in favour of shielding (national) culture. While Canada and audiovisual media exporters, such as India, Brazil and Hong Kong were important actors (WTO, 1990a), it is worthwhile mentioning that the greatest clash on media matters was between the EC and the United States (Singh, 2008: 122 and passim). This particular feature of the discourse on trade and culture set it apart from other 'trade and ...' debates, which typically involve confrontation between developed (where the US and the EU tend to share the common front) and developing countries (Lang, 2007).

When discussing the role of the EC on the international scene, it should be noted that although the EC had limited powers in cultural affairs, as the core competence remained with the member states (Craufurd Smith, 2004, 2011), it had more leeway in the field of audiovisual services. ${ }^{6}$ The Television without Frontiers Directive (TWF), adopted in 1989, is an expression of this and proved the centrepiece of the evolving and expanding European media policy (Burri, 2007; Harrison and Woods, 2007). Noteworthy in the context of the present discussion is that despite being essentially a liberalisation instrument, the TWF contained two specific provisions (Articles 4 and 5 ), which were the only tools at the Union level explicitly meant to serve cultural goals by ensuring a balance of offerings in the EU broadcasting markets. Article 4 TWF called upon the member states to ensure, where practicable and by appropriate

\footnotetext{
${ }^{4}$ The three European Communities were the 'European Economic Community' (EEC), the 'European Coal and Steel Community' (ECSC), and the 'European Atomic Energy Community' (EAEC or Euratom). It was the 'European Communities' and not the European Community or the European Union, which signed the WTO Agreements. This was due to some questions regarding the competence of the European Community in external affairs, which were subsequently clarified (Council Decision 94/800/EC of 22 December 1994, concerning the conclusion on behalf of the European Community, as regards matters within its competence, of the agreements reached in the Uruguay Round multilateral negotiations (1986-1994), OJ L 336, 23/12/1994, p. 191). As of 1 December 2009, which signals the entry into force of the Lisbon Treaty, the name used in the WTO is the European Union (EU).

${ }^{5}$ Pursuant to the technical classification scheme, which WTO members applied during the negotiations and in tailoring their concessions, the audiovisual services sector was specifically defined. It included the following sub-sectors: motion picture and video tape production and distribution services; motion picture projection services; radio and television services; radio and television transmission services; sound recording and others (WTO, 1991).

${ }^{6}$ Following the principle of subsidiarity, the EC is to encourage cooperation between the Member States but, if necessary, supplement their action in certain fields, notably in 'artistic and literary creation, including in the audiovisual sector' (Article 151(2) of the Treaty establishing the European Community (EC Treaty), now 167(2) of the Treaty on the Functioning of the European Union (TFEU).
} 
means, that broadcasters allocate a majority of time on TV channels, to Europeanmade programmes (the so-called 'European works'). Article 5 TWF was intended to secure that a minimum proportion of viewing time (10 percent) is reserved to European works created by independent producers, or alternatively that a minimum programme budget is allocated to independent productions.

The EC was undoubtedly keen to preserve these quotas (Burri, 2007; Attentional et al., 2011) and thus to make them permissible at the international level (Burri, 2009). Generally, the EC sought to secure sufficient wiggle room for cultural policy measures to be taken at both the EC and at the member state levels (very often under the influence of key players in the debate, such as notably, France).

The EU pursued these goals by relying on a set of arguments relating to the specific qualities of cultural goods and services. This underlying strategy has been typical of the EU's positioning in global governance debates bearing on culture and became truly fully-fledged after the end of the cultural exception battle and in its conceptual and institutional transformation into a cultural diversity policy (Burri, 2010a). At its very basis, such a policy is built around the two-pronged axiom that some sort of additional regulation is indispensable in markets for cultural goods and services because they fail, and that the ensuing market failures can be corrected through state intervention. ${ }^{7}$ These economic rationales have been strengthened in the political context by an enduring negative attitude towards globalisation and its effects, including or even especially those upon culture (Held et al., 1999; Cowen, 2002; Giddens, 2002). More concretely, in the WTO setting, the cultural identity line has been prominent in the tactics of the EU - on the one hand, by emphasising the importance of the audiovisual industry to European identity and unity, and by highlighting the harmful effects of the American entertainment industry, on the other (Singh, 2008: 132-133).

The EC sought to ensure that in liberalising audiovisual services, their cultural specificities would be respected, by means of an annex (WTO, 1990a). Audiovisual services, defined fairly broadly, were to be exempted to a significant extent from the obligations of most-favoured-nation (MFN), national treatment and market access (WTO, 1990a) - that is, from the core non-discrimination duties and progressive liberalisation rationale, which underlie the entire multilateral trade system.

It is fair to say that the EC was not completely united in this approach and there were various opinions within it. France has been very pro-active and a leading player. Germany and Britain were somewhat reluctant (Singh, 2008: 122-123). The European Commission, headed at the time by Jacques Delors, acted as a strong policy entrepreneur, reflecting as well as shaping the views of the member states (Ross, 1995: 115; Levy, 1999; Singh, 2008: 127). The framing of the audiovisual services matter as giving a particular behavioural profile for the EU on the international scene has had a positive feedback effect and boosted European cultural identity (Goff, 2000, 2007; Singh, 2008: 133-134). It is also to be acknowledged that the institutional design of the EU has had a clear impact on international trade negotiations designed to change the European policy status quo - Meunier argues that in such 'conservative' cases, unanimity voting and restricted delegation make the EU a tough bargainer, so

\footnotetext{
${ }^{7}$ Failures typical of markets for cultural goods and services are: a) failures due to economies of scale in production and distribution; $b$ ) failures due to the nature of competition in products with substantial public goods aspects; c) failures due to the impact of externalities on the pricing of cultural products; and d) failures due to collective action problems (Sauvé and Steinfatt, 2000; Baker, 2001).
} 
that the negotiating opponent cannot obtain more than what the most conservative EU state is willing to concede (Meunier, 2000), which in the present case is clearly France.

The US, heavily lobbied by the entertainment industry (Grant and Wood, 2004: 352376; Singh, 2008: 134-138), matched the European offensive. The US was opposed to any cultural exception, regardless of whether the exception was part of the overall framework agreement or confined to audiovisual services. Its strongest argument was that of disguised protectionism, especially considering the intrinsic difficulty of defining 'national' and 'culture'. It also stressed consumers' freedom of choice, as well as other positive effects of free trade in cultural products (WTO, 1990b). Being cautious about pushing too far on the cultural identity issue, the US had been consistent in framing the whole debate as one on trade not culture (Singh, 2008: 134135).

It merits to be noted that due to the extreme political charge of the trade and culture debate, the audiovisual services quandary almost turned into a stumbling block for the entire multilateral trade agenda (Graber, 2004), which had been designed as a 'single undertaking' and accordingly demanded agreement by all on all issues. One must at the same time also bear in mind that the audiovisual sector was only one deal amongst many and there were trade-offs and other interests within the WTO bargaining process and outside it (Braithwaite and Drahos, 2000; Singh, 2008). So, it would be wrong to isolate this contestation of trade and culture, as it should be seen in the context of both grander international cooperation deals, as well as of specific domestic circumstances and their historical evolution, such as for instance those related to the perceived role of France in culture (Meunier, 2001, 2006).

\section{The law of the WTO and the agreement to disagree}

The EU with its strongly endorsed cultural exception agenda was only partly successful at the end of the day. On paper, the text of the WTO Agreements includes no cultural exception of any kind. Such a reading does not, however, reveal the practical reality of liberalised services markets and of the policy options available. Shortly before the adoption of the Marrakesh Agreement establishing the WTO, the EC and the US agreed to disagree on addressing cultural matters without striking any concrete deal. ${ }^{8}$ This would have long-term implications for both the law of the WTO and for future endeavours to shape cultural toolkits at all levels of governance - be it national, regional or global.

The gist of the Uruguay Round results in the field of services is that while no services sector is excluded from the GATS, ${ }^{9}$ there are a number of flexibilities built in. They allow in effect the lesser opening up of certain sectors, which are sensitive to domestic constituencies (Galt, 2004). Compared to the GATT, which regulates trade

\footnotetext{
${ }^{8}$ As legend would have it, early in the morning of 14 December 1994, just before the US President's Fast Track Authority was to expire, Leon Brittan, as EU representative, offered the US Trade Representative (USTR) Mickey Kantor a deal to bind the television quota at 49 percent as part of an audiovisual services agreement and to continue negotiations on box office receipt taxes in France, as well as on blank video and audio tapes taxes. After discussions with President Clinton and Hollywood representatives, the US turned the deal down. Instead of signing something which the lobbies at home would have opposed, the USTR walked away and the Europeans made the infamous MFN exemption from the GATS (Preeg, 1995: 172; Singh, 2008: 135-136).

${ }^{9}$ Except for services supplied in the exercise of governmental authority according to Article I:3(b) GATS. For a detailed interpretation, see Krajewski (2003).
} 
in goods, the GATS offers substantially more wiggle room for national policy-makers and is less aggressive in terms of opening markets. While under the GATT, obligations regarding national treatment and quantitative restrictions apply across the board, the GATS framework adopted a 'bottom-up' (or 'positive list') approach. Thereby, WTO members can choose the services sectors and sub-sectors in which they are willing to make market access (Article XVI GATS) or national treatment (Article XVII GATS) commitments, and can define the modalities of these commitments. Even the MFN obligation - that is, the duty to treat equally all like foreign services and services suppliers, which is fundamental to the entire trade system, can be subject to limitation under the GATS (Article II:2).

As a result of this malleability in design and in spite of the considerable economic gains to be reaped from the liberalisation of audiovisual media services (Roy, 2005: 941; Singh, 2007), almost all members, with the notable exception of the US, Japan and New Zealand, have been reluctant to commit and have listed significant MFN exemptions (Roy, 2005; WTO, 2010; Shi, 2013). Indeed, audiovisual media is the least liberalised services sector. The EU and its member states have made no commitments (WTO, 1997) and tabled a number of MFN exemptions, relating mostly to extension of national treatment to audiovisual works covered by co-production agreements and support schemes, such as the MEDIA programme ${ }^{10}$ (WTO, 1994).

What is particularly interesting when looking at the members' commitments for audiovisual services, and most illustratively those of the EU, is that they reflect a resolute 'all-or-nothing' approach. The substantial scheduling flexibility permitting a wide variety of commitments ranging between full liberalisation and absolute noncommitment is not made use of. This is somewhat strange because for sub-sectors where government regulations and trade restrictions are not common, such as sound recording, there is still a ridiculously low level of commitment. In a more systemic sense, this is odd because the very goals of an international trade agreement are compromised as the absence of commitment in a given sector equals absolute freedom to take any action at a later point of time. 'This absence of any guarantee of openness stands in stark contrast to the economic and trade importance of the [audiovisual] sector (and in particular its intensive use of technology and creativity) as well as the importance of the predictability and stability given by commitments that is, the certainty that certain restrictions won't be maintained or introduced in the future' (Roy, 2005: 940-941).

The special status of audiovisual services for the EU is discernible again in the fact that for other culture-related services, such as 'printing and publishing', or 'news, press and agency services', the EU has made almost full commitments for national treatment and market access, only with some foreign ownership exceptions. Even for entertainment services, such as theatre, circus and live bands, the commitments are more nuanced and not following the 'all-or-nothing' pattern (WTO, 1997).

\footnotetext{
${ }^{10}$ The MEDIA programme has been an important EU tool for supporting the development and distribution of European films, as well as for training activities, festivals and promotion projects in the field of media. There have been four MEDIA programmes: MEDIA I (1990-1995); MEDIA II (19962000), MEDIA plus (2001-2006) and MEDIA 2007 (2007-2013). As of 2014, the newly launched 'Creative Europe' programme (2014-2020) replaces the MEDIA, MEDIA Mundus and Culture programmes. Within it, there is a MEDIA sub-programme, which supports the EU film and audiovisual industries financially in the development, distribution and promotion of their work.
} 
Despite this state of affairs, which permits almost unlimited possibilities for measures protecting domestic cultural industries and/or discriminating against foreign products and services, in political terms, the scope for domestic measures regarding trade in culture has not been found sufficient. The Uruguay Round's 'Agreement to Disagree' offered no real solution for the cultural proponents. The arguments put forward in support of this case were several: The further liberalisation commitment incorporated in the GATS (Article XIX) was impending and the MFN exemptions made were at least theoretically limited in time. ${ }^{11}$ In addition, the general exceptions available under Articles XX GATT and XIV GATS, which could justify measures otherwise violating the WTO norms in the respective products and services trade domains, were deemed insufficient to provide appropriate consideration of the pursuit of cultural objectives. Article XX(f) GATT was the notable exception because it was designed to exempt measures for the protection of 'national treasures of historic, artistic, or archaeological value'. The scope of the provision was, however, thought too limited and of little use when contemporary creative production, such as films or television programmes, was at stake. Furthermore, the norm had no counterpart under the GATS and could not help when services were affected. A particularly hard blow to the cultural exception backers had been the Canada-Periodicals case, ${ }^{12}$ which signalled the unwillingness of the WTO adjudicative bodies to engage in balancing trade versus culture values: as the case was decided by the panel and the Appellate Body to the benefit of the US, and despite CUSFTA's cultural exception clause.

\section{Doha round developments}

One could say that the post-Uruguay status quo very much resembles a de facto cultural exception. This exception is not however cast in law and is under the constant pressure of further liberalisation. The inherent insecurity has prompted the cultural exception proponents to look for solutions outside the WTO and resulted in the change of venue to the United Nations Educational, Social and Cultural Organization (UNESCO). It is noteworthy that the transition occurred under the more positive but also more ambitious agenda of cultural diversity, which was developed primarily under the International Network for Cultural Policy (INCP) and shaped by a small core of members, comprising Canada, Croatia, France, Greece, Mexico, Senegal, South Africa, Sweden and Switzerland (Burri, 2010a).

This regime-shifting, which resulted in the successful adoption of the 2005 UNESCO Convention on the Protection and Promotion of the Diversity of Cultural Expressions (Convention on Cultural Diversity or the Convention), is well documented and aptly discussed elsewhere in this volume. It suffices to say here that the EU has played a particularly prominent role in both the shaping of the concept of cultural diversity and in the developments leading towards the adoption of an international legally binding instrument, which seeks to protect national sovereignty in matters of culture (Acheson and Maule, 2004; Burri, 2010a).

As for the WTO, it is evident that although the intensity of the trade versus culture clash seems to have subsided, few changes can be expected. The Doha Development

\footnotetext{
${ }^{11}$ The GATS Annex on Article II Exemptions states that, '[i]n principle, such [MFN] exemptions should not exceed a period of 10 years. In any event, they shall be subject to negotiation in subsequent trade liberalizing rounds'. The exemptions made should have thus expired in 2005.

${ }^{12}$ WTO Panel Report, Canada-Certain Measures Concerning Periodicals (Canada-Periodicals), WT/DS31/R, adopted 14 March 1997; WTO Appellate Body Report, Canada-Certain Measures Concerning Periodicals (Canada-Periodicals), WT/DS31/AB/R, adopted 30 June 1997.
} 
Agenda (DDA), launched in 2001 (WTO, 2001), as the next round of trade negotiations, originally intended to be completed by 2005, is a proof of this. Although the DDA is not stalling because of audiovisual media services, the present state of requests and offers for the sector reveals precious few new commitments. It is also notable that despite the UNESCO Convention on Cultural Diversity and the associated mobilisation of the international community, we have not seen the formation of a negotiation bloc, which may seriously advance the cultural concerns within the WTO and seek their accommodation. Even the EU has not been particularly pro-active. It is simply pursuing its non-committal approach (WTO, 2005a), so that it remains free to keep the present and adopt future measures in the field of media services. This is despite requests by other WTO members, such as Hong Kong, Japan, Mexico and the United States, to address the status quo by either full commitments in market access and national treatment, or by more targeted actions, such as binding of the current level of market opening or commitments under specific sub-headings (commonly, film production, distribution and projection services, and sometimes sound recording) (WTO, 2005b; 2010).

Despite the recognition widely shared by key WTO members that the audiovisual sector has changed dramatically (Graber, 2004: 166-170; Roy, 2005: 931-936; WTO, 2010), in particular in the face of the convergence of information technology, telecommunications and media services, companies and sectors, and of the sweeping transformations caused by the Internet, there has been little agreement on the way forward. The trade versus culture debate has had multiple effects outside the domain of audiovisual services, as initially narrowly construed. This is particularly evident in the discussions on advancing liberalisation and coherent global regulation in the 'neighbouring' areas of telecommunications and electronic commerce (Burri, 2009), which mirror the legacy line of separation between the EU and the US.

In line with its strategy, the EU argues that '[e]lectronic deliveries consist of supplies of services which fall within the scope of the GATS' (WTO, 2000), and seeks to ensure that all digital media fall within the category of audiovisual services (WTO, 2006), thus retaining its flexibility for MFN exemptions and limited commitments. This position of the EU has been adopted in the context of its overall global trade and culture agenda (European Commission, 2007), as well as in relation to the modernisation of the TWF (now called Audiovisual Media Services Directive, $\mathrm{AVMS}^{13}$ ) to include on-demand media services too, and to prescribe soft cultural quotas for them (Burri, 2007).

The US takes the opposite position and has sought the deepest mode of liberalisation available - i.e. that of the GATT, coupled with the Information Technology Agreement $^{14}$ (WTO, 1999). The opposing agendas of the EU and the US allow no straightforward solution - an unfortunate situation, which has been exacerbated by the insufficient ability of the WTO law to adapt to rapid technological changes due to the

\footnotetext{
${ }^{13}$ Directive 2010/13/EU of the European Parliament and of the Council of 10 March 2010, on the coordination of certain provisions laid down by law, regulation or administrative action in Member States concerning the provision of audiovisual media services (Audiovisual Media Services Directive), OJ L 95, 15/4/2010, p. 1.

${ }^{14}$ The Ministerial Declaration on Trade in Information Technology Products (ITA) was concluded in Singapore in December 1996. The ITA is a plurilateral agreement that operates on a MFN basis and seeks the abolition of tariffs for certain information technology products covered by the Agreement. The ITA has been fairly successful and covers some 97 per cent of global trade in these products. It is presently committed to by 76 WTO members (Lee-Makiyama, 2011).
} 
intrinsic characteristic of the WTO as a 'member-driven' organisation (Davey and Jackson, 2008) and, specifically in the field of services, is due to the underlying and now largely outmoded services classification scheme (Weber and Burri, 2012; Tuthill and Roy, 2012). For instance, as the law presently stands, online games as a new type of cultural content platform, could be fitted into the discrete categories of computer and related services, value-added telecommunications services, entertainment or audiovisual services (Wunsch-Vincent, 2006: 71), each of which implies a completely different set of duties and flexibilities. The electronic commerce instance is illustrative of the negative spill-overs of the cultural debate, which prevent any practical solution in the short- to mid-term and leave the vital economic field of digital trade function under the conditions of substantial uncertainty. As Internet regulation matures, there is even a wave of new-generation barriers to digital trade (including localisation requirements and/or undue privacy, intellectual property and security requirements), which the WTO is unable to address, and its overall role in global digital trade governance may be so diminished (Burri, 2013a).

The lack of a solution within the multilateral context of the WTO has also prompted members to take other, bilateral or regional, paths to advance their policy priorities (Wunsch-Vincent and Hold, 2012), typically through Preferential Trade Agreements (PTAs). These are however most often the result of asymmetrical power bargains developing countries may be seriously disadvantaged when striking those deals, adopting US-centric models or unwillingly reducing future regulatory space in key areas. Overall, there is increased fragmentation of rules and complexity in governance, which may render the protection of global public goods, including cultural diversity, more difficult (Maskus and Reichman, 2005).

There have been a number of proposals in the literature to solve the 'culture versus trade' conundrum and make it more like 'culture and trade' (Burri, 2009: 45-54). One important cluster of suggestions attempts to find the appropriate linkage between the law of the WTO and the UNESCO Convention on Cultural Diversity, seeking mutual supportiveness between the two regimes and the attainment of some legal certainty through the 'harder' adjudicative mechanisms of the WTO (e.g. Graber, 2006). Another key group suggests 'renovation' of some WTO rules, whether culturespecific or not, to make the law of the WTO more suitable for the simultaneous advancement of trade liberalisation and of public interest goals of importance to members and the international community (e.g. Voon, 2007a; 2007b). Next to the various points of critique one could formulate with regard to these proposals (Voon, 2007b; Burri, 2009), a common feature is that none of them appears readily doable to a large extent due to the strong path dependence in the trade and culture debate, which almost resembles a 'dialogue of the deaf' (Roy, 2005). The WTO jurisprudence as proven by the China - Publications and Audiovisual Products case ${ }^{15}$ has so far rejected the interface between the UNESCO Convention and the WTO Agreements (Burri, 2010b; Shi, 2013).

The UNESCO Convention on Cultural Diversity has in many senses only perpetuated this dialogue, as states, parties to the Convention, seek to counteract the liberalisation

\footnotetext{
${ }^{15}$ WTO Appellate Body Report, China - Measures Affecting Trading Rights and Distribution Services for Certain Publications and Audiovisual Entertainment Products (China - Publications and Audiovisual Products), WT/DS363/AB/R, adopted 21 December 2009. The EU acted as a third party to (submissions available at: http://trade.ec.europa.eu/wtodispute/show.cfm?id=407\&code=3\#_eusubmissions).
} 
efforts under the auspices of the WTO. Yet, despite many of the flaws of the UNESCO Convention (Burri, 2009), its role should not be understated. The UNESCO Convention is an important instrument, not so much because of its potential to effectively counterbalance trade rules but because it has forcefully promoted the concept of cultural diversity - as an overarching policy goal to be taken into account domestically and at the international scene. Although the implementation efforts are advancing only at slow pace so far (Burri, 2013b), there may be some space for legal innovation down the road. The EU may be a key player in this process, as the Protocols on Cultural Cooperation negotiated by the European Commission on behalf of the EU and its Member States in the context of the new generation of EU free trade agreements show (Loisen and De Ville, 2011). The protocols are on the one hand a direct implementation effort of the UNESCO Convention but also responses to the broader changes in the EU's external policies. These changes relate to the extended competences of the Union in matters of common commercial policy after the Lisbon Treaty, ${ }^{16}$ as well as more specifically to the EU's repositioning with regard to new regional or bilateral agreements having an economic integration dimension (European Commission, 2006). The latter foresees notably that audiovisual services (including the content-related implications of electronic commerce) should be excluded from the scope of such trade agreements, and that audiovisual and other cultural services should receive special treatment under dedicated cooperation frameworks (European Commission, 2012: 24).

\section{Concluding remarks}

The trade versus culture debate has been triggered by advancing globalisation and the increasing difficulty of reconciling economic and non-economic objectives, national sovereignty and global responsibilities. The discussions have been heavily politicised and reached their pinnacle in the Uruguay Round of negotiations, which marked the highest degree of institutionalisation of economic globalisation at the international level with the establishment of the WTO. The cultural exception strategy, which has been actively endorsed by the EU, only partly achieved its goals: although the law of the WTO does not contain any exception for cultural goods and services, it permits flexibilities in particular in the field of services, which allow WTO Members to shield some sensitive sectors from liberalisation. The EU and its member states, amongst other cultural proponents, have used this opportunity to the fullest, specifically in the audiovisual services sector. As noted earlier, media services is the sector with the lowest level of commitments.

Little has changed since the conclusion of the Uruguay talks in 1994, which is odd, as we are now faced with a completely transformed media landscape. This may have led, amongst other things, to inadequacy of the existent policy measures aimed at achieving (national) cultural objectives, to negative spill-overs to other policy domains and to an overall incoherence in governance (Burri, 2009). Unfortunately very few of these problems have been appropriately addressed in the ongoing Doha

\footnotetext{
${ }^{16}$ Pursuant to Article 207 of the TFEU, EU trade policy is an exclusive EU competence for all sectors, without any sectorial carve-outs, shared competences or mixed agreements. Pre-Lisbon, there had been a carve-out for cultural and audiovisual services (Article 133(6) of the Treaty Establishing the European Union). Any agreement, which included provisions regarding cultural and audiovisual services, would so fall within the shared competence of the EU and the Member States and such mixed agreements had to be concluded together by the EU and the Member States (see e.g. Krajewski, 2005: 95-97).
} 
Round of negotiations, and it is unlikely that they will be resolved even under the highly optimistic scenario of a successful close of the Doha Round, as the cultural exception legacy endures.

Much has happened however outside the WTO. The underlying rhetoric of the trade and culture debate has been utterly transformed from 'cultural exception' to 'cultural diversity'. It has also found a new institutional home with the UNESCO and ultimately led to the adoption of the UNESCO Convention on the Protection and Promotion of the Diversity of Cultural Expressions in 2005. The Convention affirms state sovereignty in cultural matters and enjoys the broad support of the international community.

The existing international legal framework places few limitations to the EU and its member states on their cultural policy programmes for the media. Change is not to be expected soon. In this respect, it should be clearly acknowledged that 'cultural exception' policies - that is, the willingness to draw a line between economic and cultural objectives and exempt cultural goods and services from trade regulation-are still well supported. A recent reminder of this path dependent discourse has been a decision of the EU Parliament with regard to the launch of the negotiations of the Transatlantic Trade and Investment Partnership (TTIP) Agreement between the EU and the US. While the European Parliament did give green light to the TTIP, it expressly asked, under considerable influence by France, that cultural and audiovisual services, including online services, should be excluded from the negotiating mandate in order to safeguard the 'cultural exception' and protect the cultural and linguistic diversity of the EU countries (European Parliament, 2013: paras. 11-12). The campaign outside the EU institutions was even louder. It included for instance a wellpublicized petition signed by some 5,000 directors, writers, technicians, producers, distributors and exhibitors across Europe and featured high profile names like Wim Wenders, Michael Haneke, Mike Leigh, Stephen Frears and Pedro Almodovar.

The EU Parliament's resolution is however non-binding and while audiovisual services are presently not part of the negotiating mandate (Council of the European Union, 2013), Commissioner De Gucht stressed that there is a clear possibility for the Commission to "come back to the Council with additional negotiating directives after on the basis of a discussion with our US counterparts' (European Commission, 2013a). Despite this possibility, the debate itself is indicative of the strong political forces in the EU in favour of preserving the status quo of cultural exception and indeed, expanding it to online services, as well as of the great difficulty to reconcile cultural and commercial interests, even between two industrialised partners and despite the general enthusiasm towards the impending bilateral trade deal (Kanter, 2013).

In light of this path dependency and the high levels of support amongst politicians, the creative industries and the general public in the EU, one may wonder why and how policies targeted at the protection and promotion of cultural diversity could change at all. The trigger for change may lie in the new media environment. We have argued elsewhere that the digital space, while not a panacea, offers unprecedented opportunities to cater for a vibrant and diverse cultural environment. We suggest that three paths for policy experimentation are particularly worthwhile considering in this regard: a) responding to the creative user; b) responding to the unlimited 'shelf-space' in cyberspace; and c) taking into account policies conventionally thought peripheral to 
achieving cultural objectives and often falling outside the traditional media law and policy domain, as conceived pre-digitization and pre-convergence (Burri, 2012a).

The EU has already launched some projects, such as Europeana: the European Digital Library, which reflect the changes brought about by the Internet, as well as use its affordances to attain important policy objectives - such as in this case, multilingual access to Europe's distributed cultural heritage. ${ }^{17}$ There is in addition a growing awareness amongst the EU institutions that policies need to be adapted too. The Green Paper on Preparing for a Fully Converged Audiovisual World: Growth, Creation and Values (European Commission, 2013b) is a good basis to start such a 'renovation' project, although it remains to be seen how this project will be carried on and in general, how the EU would implement its goal to 'mainstream' culture and make cultural diversity a valid policy objective in domains beyond audiovisual media (European Commission, 2007). It remains also to be seen whether the EU-wide policy transformations would lead to any changes in the EU's stance at the WTO, or whether the preservation of the policy space will continue to be the preferred option. The TTIP and the US pressure may potentially trigger some rethinking.

In implementing its cultural diversity policies, the EU (or any other global player) would need to consider not only the practical reality of contemporary media but also the changes in global governance. These are characterised by ailing multilateralism, intensified forum-shopping, proliferating PTAs, repositioning of traditional world powers and the emergence of new and stronger actors, to name but a few trends (Jackson, 2007; Cottier and Delimatsis, 2011; WTO, 2011). The emergent modes of cyber-governance, characterised by unilateral state action with global reach, regulation through intermediaries and through technology, only compound the existing complexity (Benkler, 2006; Lessig, 1999, 2006; Burri, 2012b). Against this backdrop, any future solution to the trade and culture quandary appears unlikely in the forum of the WTO or in the UNESCO alone, and would have to match the reality of multi-level, multi-domain governance in the attempt to reconcile economic and noneconomic objectives.

\section{References:}

Acheson, K. and Maule, C. (2004) 'Convention on Cultural Diversity', Journal of Cultural Economics, 28, 243-256.

Attentional et al. (2011) Study on the Implementation of the Provisions of the Audiovisual Media Services Directive Concerning the Promotion of European Works in Audiovisual Media Services, Prepared for the European Commission.

\footnotetext{
${ }^{17}$ Europeana was launched in November 2008 and allows Internet users to search and get direct access to digitised books, maps, paintings, newspapers, film fragments and photographs from Europe's cultural institutions. Presently some 29 million objects from more than 2,200 institutions from 36 countries are made available on Europeana with numbers constantly rising. The content is also socially connected in various sites and platforms, available through an iPad app, downloadable and malleable under different copyright licensing regimes (such as the creative commons licence). In this sense, Europeana not only aggregates content but builds an open, trusted source of cultural heritage, which is also meant to engage users in new ways of participating in their cultural heritage, facilitate knowledge transfer, innovation and advocacy in the cultural heritage sector.
} 
Baker, C. E. (2001) Media, Markets, and Democracy (Cambridge: Cambridge University Press).

Benkler, Y. (2006). The Wealth of Networks: How Social Production Transforms Markets and Freedom (New Haven: Yale University Press).

Braithwaite, J., and Drahos, P. (2000) Global Business Regulation (Cambridge: Cambridge University Press).

Bruner, C. M. (2008) 'Culture, Sovereignty, and Hollywood: UNESCO and the Future of Trade in Cultural Products', International Law and Politics, 40, 351-436.

Burri, M. (2007) 'The New Audiovisual Media Services Directive: Television without Frontiers, Television without Cultural Diversity', Common Market Law Review, 44, $1689-1725$.

Burri, M. (2009) 'Trade versus Culture in the Digital Environment: An Old Conflict in Need of a New Definition', Journal of International Economic Law, 12, 17-62.

Burri, M. (2010a) 'Cultural Diversity as a Concept of Global Law: Origins, Evolution and Prospects', Diversity, 2, 1059-1084.

Burri (2010b) 'Trade and Culture in International Law: Paths to (Re)conciliation', Journal of World Trade, 44, 49-80.

Burri, M. (2012a) 'Cultural Protectionism 2.0: Updating Cultural Policy Tools for the Digital Age', in S. Pager and A. Candeub (eds) Transnational culture in the Internet Age (Cheltenham: Edward Elgar).

Burri, M. (2012b) 'Controlling New Media (without the Law)', in M. Price and S. Verhulst (eds) Handbook of Media Law and Policy (Abington: Routledge).

Burri (2013a) 'Should There Be Multilateral Rules for Digital Trade?', Report prepared for the ICTSD e15 experts' dialogue on trade and innovation, September.

Burri (2013b) 'The UNESCO Convention on Cultural Diversity: An Appraisal Five Years after its Entry into Force', International Journal of Cultural Property, 20, 124.

Cottier, T. and Delimatsis, P. (2011) The Prospects of International Trade Regulation: From Fragmentation to Coherence (Cambridge: Cambridge University Press).

Council of the European Union (2013) 3245th Council Meeting Foreign Affairs and Trade, Press Release (10862/13, 14 June 2013).

Cowen, T. (2002) Creative Destruction: How Globalization Is Changing the World's Cultures (Princeton: Princeton University Press).

Craufurd Smith, R. (ed) (2004) Culture and European Union Law (Oxford: Oxford University Press).

Craufurd Smith, R. (2011) 'The Evolution of Cultural Policy in the EU', in P. Craig and G. de Búrca (eds) The Evolution of EU Law (Oxford: Oxford University Press), $872-895$.

Davey, W. J. and Jackson, J. H. (2008) The Future of International Economic Law (Oxford: Oxford University Press).

European Commission (2005) i2010: Digital Libraries, COM(2005) 465 final. 
European Commission (2006) Global Europe: Competing in the World, COM(2006) 567 final.

European Commission (2007) European Agenda for Culture in a Globalizing World $\operatorname{COM}(2007) 242$ final.

European Commission (2009) Europeana: Next Steps, COM(2009) 440 final.

European Commission (2012) Quadrennial Periodic Report on Behalf of the European Union on Measures to Protect and Promote the Diversity of Cultural Expressions in the Framework of the 2005 UNESCO Convention, Accompanying the Document Report on Measures to Protect and Promote the Diversity of Cultural Expressions in the Framework of the 2005 UNESCO Convention, SWD(2012) 129 final.

European Commission (2013a) 'Transatlantic Trade and Investment Partnership: Commissioner Karel De Gucht Welcomes Member States' Green Light to Start Negotiations', Press Release (IP/13/548, 14 June 2013).

European Commission (2013b) Green Paper on Preparing for a Fully Converged Audiovisual World: Growth, Creation and Values, COM(2013) 231 final

European Parliament (2013) Resolution on EU trade and investment negotiations with the United States of America, 2013/2558(RSP).

Footer, M. E. and Graber, C. B. (2000) 'Trade Liberalisation and Cultural Policy', Journal of International Economic Law, 3, 115-144.

Galt, F. S. (2004) 'The Life, Death, and Rebirth of the "Cultural Exception" in the Multilateral Trading System', Washington University Global Studies Law Review, 3, 909-935.

Giddens, A. (2002) Runaway World: How Globalisation Is Reshaping Our Lives (Abington: Routledge).

Goff, P. M. (2000) 'Invisible Borders: Economic Liberalization and National Identity', International Studies Quarterly, 44, 533-562.

Goff, P. M. (2007) Limits to Liberalization: Local Culture in a Global Marketplace (Ithaca: Cornell University Press).

Graber, C. B. (2004) 'Audio-visual Policy: The Stumbling Block of Trade Liberalisation', in D. Geradin and D. Luff (eds) The WTO and Global Convergence in Telecommunications and Audiovisual Services (Cambridge: Cambridge University Press), 165-214.

Graber, C. B. (2006) 'The New UNESCO Convention on Cultural Diversity: A Counterbalance to the WTO', Journal of International Economic Law, 9, 553-574.

Grant, P. S. and Woods, C. (2004). Blockbusters and Trade Wars: Popular Culture in a Globalized World (Vancouver: Douglas and McIntyre).

Harrison, J. and Woods, L. (2007) European Broadcasting Law and Policy (Cambridge: Cambridge University Press).

Held, D., McGrew, A., Goldblatt, D. and Perraton, J. (1999) Global Transformations: Politics, Economics and Culture (Stanford: Stanford University Press).

Jackson, J. H. (1997) The World Trading System: Law and Policy of the International Economic Relations (Cambridge, MA: MIT Press). 
Jackson, J. H. (2007) 'International Economic Law: Complexity and Puzzles', Journal of International Economic Law, 10, 3-12.

Kanter, J. (2013) 'European Parliament Moves to Limit Scope of Eventual U.S. Trade Deal', The New York Times, 23 May.

Krajewski, M. (2003) 'Public Services and Trade Liberalization: Mapping the Legal Framework', Journal of International Economic Law, 6, 341-367.

Krajewski, M. (2005) 'External Trade Law and the Constitution Treaty: Towards a Federal and More Democratic Common Commercial Policy', Common Market Law Review, 42, 91-127.

Lang, A. T. F. (2007) 'Reflecting on "Linkage": Cognitive and Institutional Change in the International Trading System', The Modern Law Review, 70, 523-549.

Lee-Makiyama, H. (2011) 'Future-Proofing World Trade in Technology: Turning the WTO IT Agreement (ITA) into the International Digital Economy Agreement (IDEA)', ECIPE Working Paper, 4.

Lessig, L. (1999). Code and Other Laws of Cyberspace (New York: Basic Books).

Lessig, L. (2006) Code: Version 2.0 (New York: Basic Books).

Levy, D. A. (1999) Europe's Digital Revolution: Broadcasting Regulation, the EU and the Nation State (Abington: Routledge).

Loisen, J. and De Ville, F. (2011) 'The EU-Korea Protocol on Cultural Cooperation: Toward Cultural Diversity or Cultural Deficit?', International Journal of Communication, 5, 254-271.

Maskus, K. E. and Reichman, J. H. (2005) (eds) International Public Goods and Transfer of Technology under a Globalized Property Regime (Cambridge: Cambridge University Press).

Meunier, S. (2000) 'What Single Voice? European Institutions and EU-US Trade Negotiations', International Organization, 54, 103-135.

Meunier, S. (2001) The French Challenge: Adapting to Globalization (Washington, DC: Brookings Institutions Press).

Meunier, S. (2006) 'The Distinctiveness of French Anti-Americanism', in Peter J. Katzenstein and Robert Keohane (eds) Anti-Americanisms in World Politics (Ithaca: Cornell University Press), 129-156.

Petito, D. S. (2001) 'Sovereignty and Globalization: Fallacies, Truth, and Perception', New York Law School Journal of Human Rights, 17, 1139-1172.

Preeg, E. H. (1995) Traders in a Brave New World: The Uruguay Round and the Future of the International System (Chicago: University of Chicago Press).

Ross, G. (1995) Jacques Delor and European Integration (Oxford: Polity).

Roy, M. (2005) 'Audiovisual Services in the Doha Round: Dialogue de Sourds, the Sequel?', Journal of World Investment and Trade, 6, 923-952.

Sauvé, P. and Steinfatt, K. (2000) 'Towards Multilateral Rules on Trade and Culture: Protective Regulation or Efficient Protection?', in Productivity Commission and Australian National University (eds) Achieving Better Regulation of Services (Canberra: AusInfo), 323-346. 
Shi, J. (2013) Free Trade and Cultural Diversity in International Law (Oxford: Hart).

Singh, J. P. (2007) 'Culture or Commerce? A Comparative Assessment of International Interactions and Developing Countries at UNESCO, WTO, and Beyond', International Studies Perspectives, 8, 36-53.

Singh, J. P. (2008) Negotiation and the Global Information Economy (Cambridge: Cambridge University Press).

Trumpbour, J. (2007) Selling Hollywood to the World: US and European Struggles for Mastery of the Global Film Industry, 1920-1950 (Cambridge: Cambridge University Press).

Tuthill, L. and Roy, M. (2012) 'GATS Classification Issues for Information and Communication Technology Services', in M. Burri and T. Cottier (eds) Trade Governance in the Digital Age (Cambridge: Cambridge University Press), 157-178.

Weber, R. H. and Burri, M. (2012) Classification of Services in the Digital Economy (Berlin: Springer).

WTO (1990a) Working Group on Audiovisual Services, Communication from the European Communities, Draft Sectoral Annex on Audiovisual Services (MTN.GNS/AUD/W/2).

WTO (1990b) Working Group on Audiovisual Services, Note on the Meeting of 5 and 18 October 1990 (MTN.GNS/AUD/2).

WTO (1991) Services Sectoral Classification List (Doc.MTN.GNS/W/120).

WTO (1994) European Communities and their Member States, Final List of Article II (MFN) Exemptions (GATS/EL/31).

WTO (1997) European Communities and their Member States, Schedule of Specific Commitments, Trade in Services, Supplement 3 (GATS/SC/31/Suppl. 3).

WTO (1999) Work Programme on Electronic Commerce: Submission by the United States (WT/COMTD/17; WT/GC/16; G/C/2; S/C/7; IP/C/16).

WTO (2000) WTO, Communication from the European Communities and their Member States: Electronic Commerce Work Programme (S/C/W/183).

WTO (2001) WTO, Doha Ministerial Declaration (WT/MIN(01)/DEC/W/1).

WTO (2005a) Communication from the European Communities and its Member States, Conditional Revised Offer (TN/S/O/EEC/Rev.1).

WTO (2005b) Communication from Hong Kong China, Japan, Mexico, the Separate Customs Territory of Taiwan, Penghu, Kinmen and Matsu, and United States, Joint Statement on the Negotiations on Audiovisual Services (TN/S/W/49).

WTO (2006) Communication from the European Communities and its Member States, Draft consolidated GATS Schedule (S/C/W/273).

WTO (2010) Council for Trade in Services, Audiovisual services, Background note by the secretariat $(\mathrm{S} / \mathrm{C} / \mathrm{W} / 310)$.

WTO (2011) The WTO and Preferential Trade Agreements: From Co-existence to Coherence (Geneva: WTO).

Wunsch-Vincent, S. (2006) The WTO, the Internet and Trade in Digital Products: EU-EC Perspectives (Oxford: Hart). 
Wunsch-Vincent, S. and Hold. A. (2012) Towards Coherent Rules for Digital Trade: Building on Efforts in Multilateral versus Preferential Trade Negotiations', in M. Burri and T. Cottier (eds) Trade Governance in the Digital Age (Cambridge: Cambridge University Press), 179-221.

Voon, T. (2007a) Cultural Products and the World Trade Organization (Cambridge: Cambridge University Press).

Voon, T. (2007b) 'A New Approach to Audiovisual Products in the WTO: Rebalancing GATT and GATS', UCLA Entertainment Law Review, 14, 1-32. 